International Journal of Advanced Chemistry, 9(2)(2021) 74-79
International Journal of Advanced Chemistry
SPC
Website: www.sciencepubco.com/index.php/IJET
Research paper

\title{
Physico-chemical and combustion analyses of bio-briquettes from biochar produced from pyrolysis of groundnut shell
}

\author{
Ige Ayodeji Rapheal ${ }^{1 *}$, Elinge Cosmos Moki ${ }^{1}$, Aliyu Muhammad ${ }^{1}$, Gwani \\ Mohammed $^{2}$, Lawal Gusau Hassan ${ }^{3}$, Abubakar Umar BirninYauri ${ }^{1}$ \\ ${ }^{1}$ Department of Pure and Applied Chemistry, Kebbi State University of Science and Technology, Aliero, Kebbi State, Nigeria \\ ${ }^{2}$ Department of Physics, Kebbi Sate University of Science and Technology, Kebbi State, Nigeria \\ ${ }^{3}$ Department of Pure and Applied Chemistry, Usmanu Danfodiyo University, Sokoto, Nigeria \\ *Corresponding author E-mail:igeayodeji2@gmail.com
}

\begin{abstract}
The initiative of using biomass as a preference source of energy is vindicated by its availability, abundance, easy accessibility and its eco-friendly nature. This therefore calls for the conversion of agricultural wastes to usable form. This study is aimed to investigate the physicochemical and combustion properties of briquettes obtained from pyrolyzed biochar of groundnut shell. The groundnut shell biochar briquette bonded with cassava starch as binder were molded and analyzed. Proximate analysis, ultimate analyses, Scanning electron microscopy (SEM), Calorific values, density and compressive strength, among other properties, were determined for the fabricated briquettes. A high heating value of $42.50 \mathrm{MJ} / \mathrm{Kg}$ was recorded for groundnut shell biochar briquette compared to $25.20 \mathrm{MJ} / \mathrm{Kg}$ of raw groundnut shell briquette. While the ash contents of $5.12 \%$ and $6.40 \%$ were recorded for raw groundnut shell briquette and groundnut shell biochar briquette respectively. It took groundnut shell biochar briquette approximately 10 minutes to boil $1000 \mathrm{~cm} 3$ of water, while raw groundnut shell briquette boiled same quantity of water in 20 minutes. The finding of this study shows that the biochar obtained from the pyrolysis of groundnut shell is suitable for fuel briquette production.
\end{abstract}

Keywords:Pyrolyisis; Groundnut Shell; Biochar; Briquette; Cassava Starch.

\section{Introduction}

Biomass is the third major primary energy means in the world which is considered as renewable energy source for both developed and developing countries [1]. The key percentage of biomass energy is made from wood and wood wastes (64\%), solid waste (24\%), agricultural waste (5\%) and land fill gases [2]. Biomass has grown importance as one of the generally utilized sources of renewable energy fuel due to increasing global energy desires by teeming world population and rapid industrialization and urbanization [3-6].

Biomass-to-energy is an encouraging alternative energy technology [7]. Current studies have revealed that biomass energy conversion is one of the few confirmed, cost-effective and accessible technologies that can reduce $\mathrm{CO}_{2}$ emissions [8]. These findings are based on the impacts on climate change caused mainly by the use of fossil fuels [9].

Pyrolysis product (biochar) has many applications [10]. However, factors, such as high water and ash contents, instability, heating value restrict the utilization of biochar. Therefore, improving the biochar becomes inevitable to increase its quality [11].

Groundnut shells are common agricultural residues in Nigeria which are available in abundance most especially in Northern region of Nigeria. These are either burnt or disposed of in a manner that could bring environmental pollution. Research paper states that the calorific value of the Gmelina arborea biochar briquette reported by Adegoke et al., [12] is $32.82 \pm 1.125 \mathrm{MJ} / \mathrm{kg}$.

Nurhayati et al., [13] reported the proximate and mechanical analysis of carbonized biochar briquette produced from palm karnel shell. The volatile matter obtained is $55.95 \%$, ash content shows $4.83 \%$, fixed carbon content and moisture content show $39.22 \%$ and $1.75 \%$ respectively. Compressive strength obtained is around $3.20 \mathrm{MPa}$ while the density obtained is $0.94 \mathrm{~g} / \mathrm{cm}^{3}$ and calorific value obtained is around $29.60 \mathrm{MJ} / \mathrm{kg}$.

Enough investigations are seen in the previous studies on groundnut shell for briquette production, and no study is seen for the groundnut shell via pyrolysis for briquette production. Hence, this study is expected to produce and analyzed briquette from the groundnut shell pyrolyzed biochar.

\section{Material and methods}

\subsection{Material}


The both raw groundnut shell and biochar left over from the pyrolysis of groundnut shell of Ige et al., [14] were collected for the production of briquette. The biochars and raw groundnut shells were sieved with $2 \mathrm{~mm}$ wire mesh to reduce the particle size into fine particles and were stored in air-tight containers until further use.

\subsection{Briquette production}

The briquettes were produced using a fabricated briquetting machine which works on 10 ton hydraulic jack that press a chamber of a cylindrical mould confining the slurry. The length and the breadth of briquettes are $94 \mathrm{~mm}$ and $61 \mathrm{~mm}$ respectively. Cassava starch was procured from Kuto market, Abeokuta, Ogun State and was used as binder. The dried samples of biochar from groundnut shell raw groundnut shell were weighed, mixed in ratio 4:1 thoroughly with water to form slurry and fed into the mould to produce briquette and the briquettes were sun dried for two weeks as shown in Figure 1.

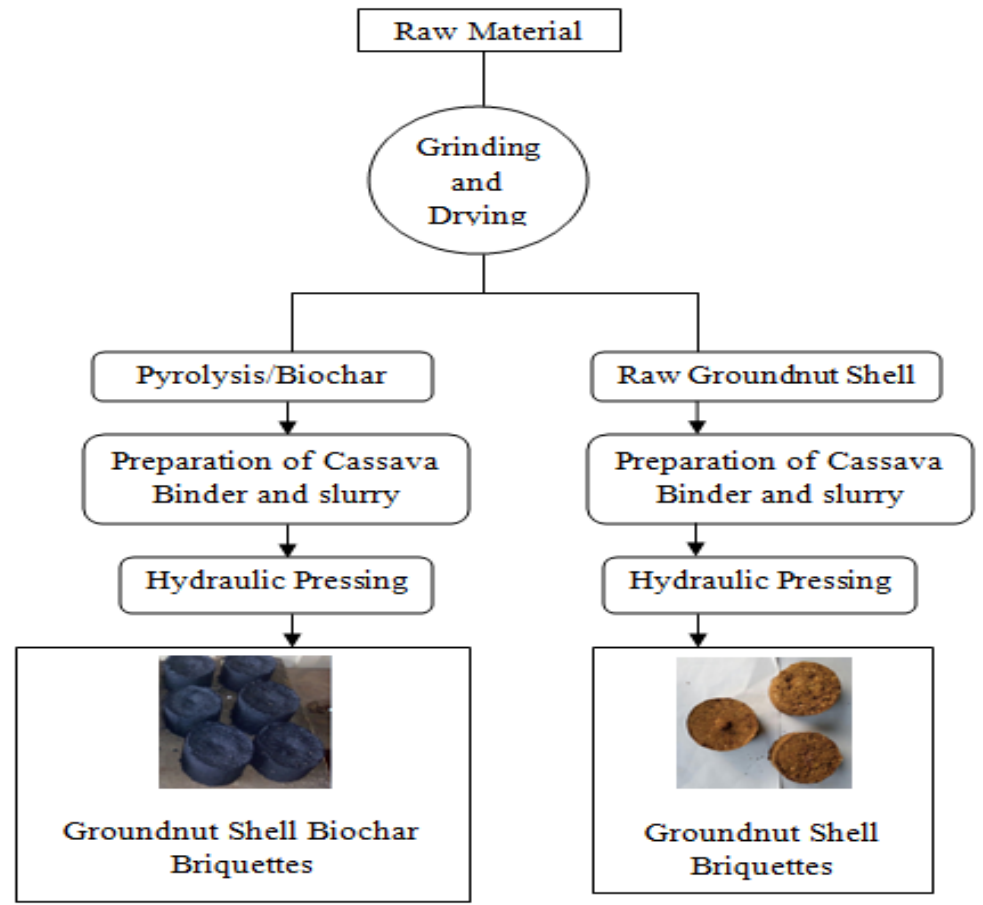

Fig. 1: Flow Chart of Briquettes Production.

\subsection{Determination of proximate, ultimate and combustion properties}

Proximate analysis (Ash, volatile matter, moisture content and fixed carbon) was conducted in accordance with the JIS-M8813. The ultimate analysis of the raw and biochar samples was determined by the element analyzer (CHNS analyzer ASTM D5291 method) and Oxygen was calculated according to Sallau et al., [15] procedure.

The calorific value was determined using LECO AC 350 Bomb calorimeter following standard procedure [16]. Density was determined according to Obi et al., [16] procedure.

Compressive strength of the briquette sample was determined using ELE tritest 50 compression machines according to Olawale et al., [17]. The water boiling test was examined by recording the time taken for a given mass of $1000 \mathrm{~g}$ of the briquette sample to first boil $1000 \mathrm{ml}$ of water under similar conditions, ignition time and afterglow were determined according to Onuegbu et al., [18].

The presence of a surface functional group of biochar and raw materials was analysed using Fourier transform infrared (FTIR) (Spectrum100, Perkin Elmer) transmission analysis.

\subsection{Scanning electron microscopy}

The micro-structure of the samples was analyzed by Scanning Electron Microscopy (SEM) at the Umaru Musa Yar'adua University Analytical Laboratory Katsina State. The samples were first transferred to capsules and coated with Palladium (Pd) at $30 \mathrm{~mA}$ and analyzed in a JEOLJFC-5510LV Scanning Electron Microscope.

Statistical Analysis: The average of all the parameters analyzed was computed by pair T-test using Graph Pad Prism® (Version 6.04) and results were presented as mean $\pm \mathrm{SEM}$.

\section{Results}

Table 1: Proximate Composition of the Raw and Biochar Sample Materials

\begin{tabular}{lllll}
\hline Samples & Moisture & Ash & Volatile & Fixed \\
\hline Content & Content & Matter & Carbon & $(\%)$ \\
& $(\%)$ & $(\%)$ & $(\%)$ & $10.91 \pm 0.34$ \\
RGS & $9.40 \pm 0.23$ & $4.42 \pm 0.42$ & $75.27 \pm 0.05$ & $79.60 \pm 0.45$ \\
BGS & $4.50 \pm 0.34$ & $5.28 \pm 0.05$ & $10.62 \pm 0.12$ & \\
\hline
\end{tabular}

Data are means of three replicates $(\mathrm{n}=3) \pm$ SD using Graph Pad Prism. RGS:Raw Groundnut Shell, BGS:Biochar Groundnut Shell. 
Table2: Ultimate Analysis of the Raw and Biochar Sample Materials

\begin{tabular}{llllll}
\hline Samples & $\mathrm{C}$ & $\mathrm{H}$ & $\mathrm{O}$ & $\mathrm{N}$ \\
$(\mathrm{wt} \%)$ & $(\mathrm{wt} \%)$ & $\begin{array}{l}\mathrm{S} \\
(\mathrm{wt} \%)\end{array}$ & $0.16 \pm 0.50$ \\
\hline RGS & $47.10 \pm 0.23$ & $6.83 \pm 0.01$ & $42.63 \pm 0.03$ & $3.28 \pm 0.24$ & $0.57 \pm 0.22$ \\
BGS & $68.72 \pm 0.14$ & $3.24 \pm 0.31$ & $28.45 \pm 0.04$ & $0.02 \pm 0.11$ \\
\hline
\end{tabular}

Data are means of three replicates $(\mathrm{n}=3) \pm$ SD using Graph Pad Prism. RGS:Raw Groundnut Shell, BGS:Biochar Groundnut Shell.

Table 3: Proximate Composition of the Raw and Biochar Sample Briquettes

\begin{tabular}{lllll}
\hline Samples & $\begin{array}{l}\text { Moisture Content } \\
(\%)\end{array}$ & $\begin{array}{l}\text { Ash Content } \\
(\%)\end{array}$ & $\begin{array}{l}\text { Volatile Matter } \\
(\%)\end{array}$ & $(\%)$ \\
\hline RGS & $6.83 \pm 0.57$ & $5.12 \pm 0.20$ & $71.89 \pm 0.50$ & $16.16 \pm 0.02$ \\
BGS & $5.71 \pm 0.52$ & $6.40 \pm 0.68$ & $12.30 \pm 0.03$ & $75.59 \pm 0.11$ \\
\hline
\end{tabular}

Data are means of three replicates $(\mathrm{n}=3) \pm$ SD using Graph Pad Prism. RGS:Raw Groundnut Shell, BGS:Biochar Groundnut Shell.

Table 4:Physical Characteristics of the Raw and Biochar Sample Briquettes

\begin{tabular}{llll}
\hline Samples & Density $\left(\mathrm{g} / \mathrm{cm}^{3}\right)$ & $\begin{array}{l}\text { Compressive } \\
\text { Strength }\left(\mathrm{N} / \mathrm{mm}^{2}\right)\end{array}$ & $\begin{array}{l}\text { Calorific Value } \\
(\mathrm{MJ} / \mathrm{Kg})\end{array}$ \\
\hline RGS & $0.62 \pm 0.24$ & $0.94 \pm 0.50$ & $25.20 \pm 0.34$ \\
BGS & $1.45 \pm 0.23$ & $3.66 \pm 0.04$ & $42.50 \pm 0.10$ \\
\hline
\end{tabular}

Data are means of three replicates $(\mathrm{n}=3) \pm$ SD using Graph Pad Prism. RGS:Raw Groundnut Shell, BGS:Biochar Groundnut Shell

Table 5: Combustion Characteristics of the Raw and Biochar Sample Briquettes

\begin{tabular}{llll}
\hline Samples & $\begin{array}{l}\text { Ignition Time } \\
(\mathrm{cm} / \mathrm{s})\end{array}$ & $\begin{array}{l}\text { Afterglow } \\
(\mathrm{sec})\end{array}$ & $\begin{array}{l}\text { Combustibility } \\
\text { Test(mins })\end{array}$ \\
\hline RGS & $0.52 \pm 0.30$ & $44 \pm 0.12$ & $20 \pm 0.64$ \\
BGS & $1.18 \pm 0.01$ & $63 \pm 0.18$ & $10 \pm 0.01$ \\
\hline
\end{tabular}

Data are means of three replicates $(n=3) \pm$ SD using Graph Pad Prism. RGS:Raw Groundnut Shell, BGS:Biochar Groundnut Shell

Table 6: FT-IR Characteristics of Raw and Biochar Materials

\begin{tabular}{lllll}
\hline RGS & BGS & Range $\left(\mathrm{cm}^{-1}\right)$ & Functional Group & Characteristics \\
\hline 3275 & - & $3570-3200$ & OH & Broad \\
2918 & - & $2935-2915$ & C-H & Methylene, assy/sym stretch \\
1622 & 1562 & $1650-1566$ & C = C & Cyclo Alkene stretch \\
1424 & - & $1450-1335$ & C-H & Bending Vibration \\
1026 & 1033 & $1150-1000$ & C-H & C-O stretch vibration of ester \\
\hline
\end{tabular}

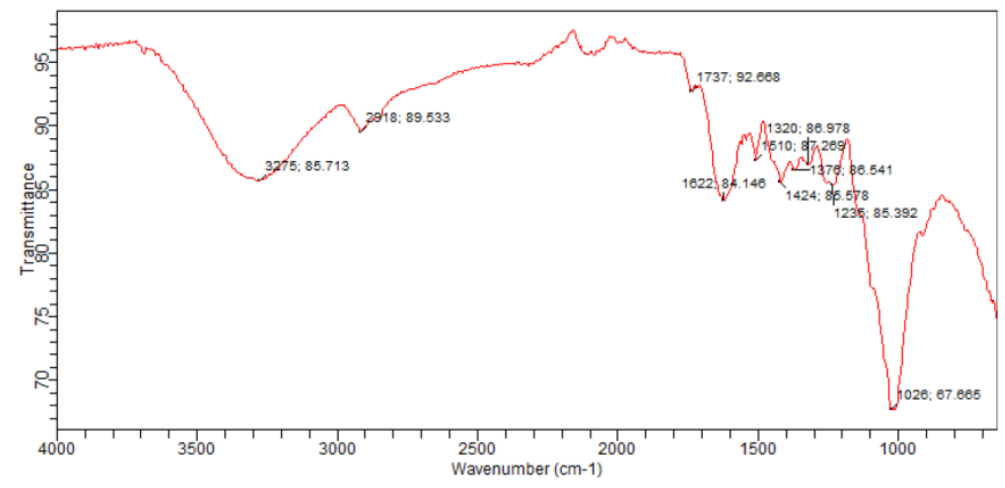

Fig. 2: FTIR Spectral of Raw Groundnut Shell.

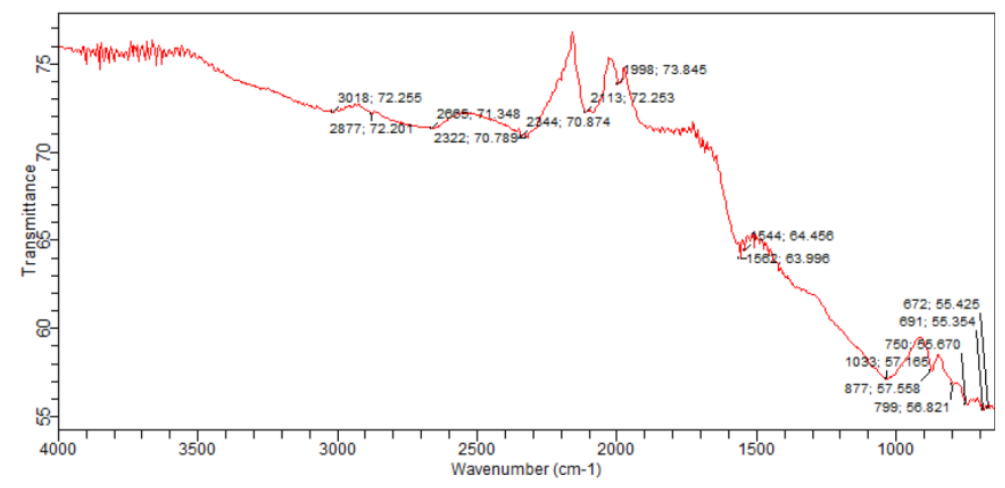

Fig. 3: FTIR Spectral of Groundnut Shell Biochar. 


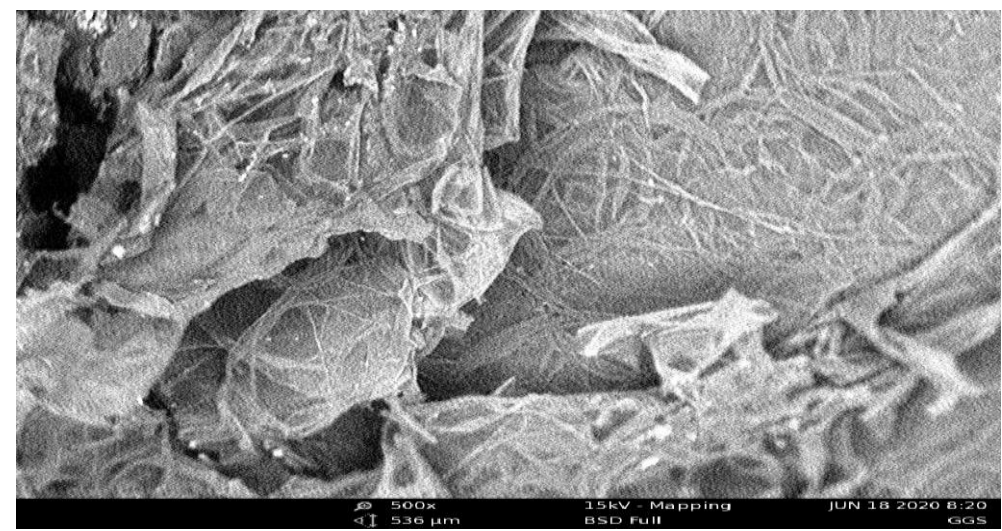

Fig.4:The SEM Image of Raw Groundnut Shell at 500 Magnification.

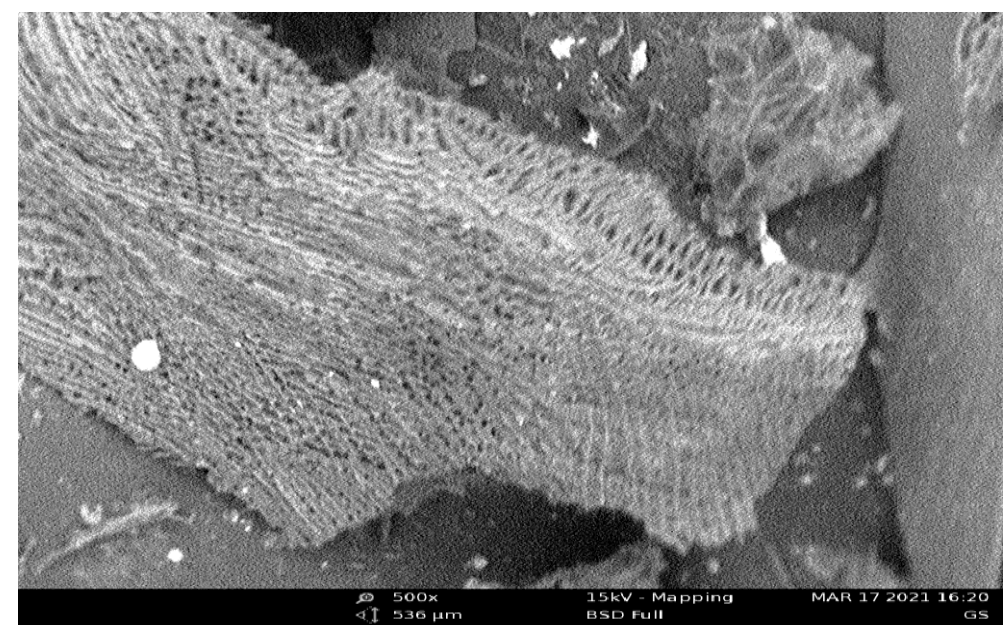

Fig. 5: The SEM Image of Groundnut Shell Biochar at 500 Magnification.

\section{Discussion}

Table 1 and 2 show the proximate, ultimate and heating value of the raw samples (groundnut shell and pyrolyzed biochar samples groundnut shell), used for the study. The volatile matter content, moisture content and ash content for the raw samples are higher than that of biochar samples for groundnut shell while the fixed carbon and the heating value of the biochar sample are higher than that of raw sample for groundnut shell. This could be due to the pyrolysis process. The volatile matter obtained for the samples are lower than that of the finding reported by Lasode et al. [19] and Prins et al. [20], where the studies reported $82.3 \mathrm{wt} \%$ for teak dust and $79.0 \mathrm{wt} \%$ for Switchgrass dust, respectively. It was reported that a high concentration of volatiles will be released during pyrolysis at high temperature and part of the volatiles could be trapped within the carbon matrix of biomass, forming secondary char that contributes to a high $\mathrm{C} \%$ [21].

The results of ultimate analysis of the raw groundnuts shell sample gave $47.10 \%, 6.83 \%, 42.63 \%, 3.28 \%$ and $0.16 \%$ for contents of carbon, hydrogen, oxygen, nitrogen and sulphur respectively while pyrolyzed groundnut shell biochar gave $68.72 \%, 3.24 \%, 28.45 \%, 0.57 \%$ and $0.02 \%$ for contents of carbon, hydrogen, oxygen, nitrogen and sulphur respectively. There is an improvement in the amount of carbon and less reduction in hydrogen content in the pyrolyzed materials which is very suitable as they contribute enormously to the combustibility of any substance in which they are initiated. The analyses of the selected raw materials to produce briquettes before and after pyrolysis provide some novelty. The influence and link to the briquette production process were investigated.

Table 3 shows that there is a significant difference in the moisture content of the briquette samples at $\mathrm{P}<0.05$ in which mean \pm SEM values of $6.83 \%$, and $5.71 \%$ were recorded for raw groundnut shell briquette and groundnut shell biochar briquette. The results of moisture content obtained are compared well with that of biochar briquette produced from pyrolysis of palm kernel (1.75\%) as reported by Nurhayati et al., [13]. Moisture content value greater than $20 \%$ may have a marked effect on the stored or residual energy needed for the complete combustions of the fuel for water evaporation at the expense of the fuels calorific value. This may have an effect on the shelf life of the briquette [17 \& 22].

High ash content is an indicator that helps to determine the dust emission rate of a briquette. Its general value may appear in a range of 5$20 \%$. Any values above this may result to environmental pollution [ $23 \& 24]$. The ash contents of $5.12 \%$, and $6.40 \%$ were recorded for raw groundnut shell briquette and groundnut shell biochar briquette at $\mathrm{P}<0.05$. The results of ash content obtained in this study are lower than the result of $16.5 \%$ reported by Carnaje et al., [25] for charcoal briquettes from water hyacinth (Eichhornia crassipes). A low ash content value signifies a better quality of the briquettes.

Also, the volatile matter of $71.89 \%$, and $12.30 \%$ were recorded for raw groundnut shell briquette and groundnut shell biochar briquette at $\mathrm{P}<0.05$ respectively. A significant difference of 0.0054 was observed in the recorded mean volatile matter values. The combustibility of a briquette fuel also depends on the volatile matter content. The higher the volatile matter of a fuel briquette the higher its combustibility, provided low ash content is recorded [26].

The recorded values for the fixed carbon (Table 3) shows a significant difference of 0.0003 at $\mathrm{P}<0.05$ in which groundnut shell biochar briquette has a higher fixed carbon content of $75.59 \%$ compared to the other briquette sample. The lower value recorded for raw groundnut shell briquette is an indication of prolonged cooking time with a very low rate of heat release [27]. The finding of this study in which the higher mean calorific value as well as the fixed carbon content of groundnut shell biochar briquette corroborates the statement 
earlier reported that in order to obtain a briquette of high quality, there must be a synchrony between calorific value and fixed carbon content [28] in which a high value of both parameters must be obtained.

Furthermore, heating value is regarded as one of the essential parameters to be considered thus determining the usage of any potential fuel to serve its purpose. A high heating value of $42.50 \mathrm{MJ} / \mathrm{Kg}$ was recorded for groundnut shell biochar briquette compared to 25.20 $\mathrm{MJ} / \mathrm{Kg}$ of raw groundnut shell briquette at $\mathrm{P}<0.05$ as shown in Table 4 . From the results, groundnut shell biochar briquette recorded a higher heating value and this could be due to pyrolysis. The values obtained are compared well to those earlier reported from previous findings, for example; biochar palm kernel briquette [13], $11.99 \mathrm{MJ} / \mathrm{kg}$ watermelon peel briquette [21], 18.60 MJ/Kg rice husk briquette [29] and $28.61 \pm 0.81$ Gmelina arborea biochar briquette [12]. However, this may be attributed to the high density, lower volatile matter, and high fixed carbon.

The density values of $0.62 \mathrm{~g} / \mathrm{cm}^{3}$, and $1.45 \mathrm{~g} / \mathrm{cm}^{3}$ were recorded for raw groundnut shell briquette, and groundnut shell biochar briquette at $\mathrm{P}<0.05$ as shown in Table 4 . The obtained density value was observed to be compared well to the reported value of $0.89 \pm 0.06 \mathrm{~g} / \mathrm{cm}^{3}$ charcoal briquettes from water hyacinth (Eichhornia crassipes) [24] and banana peel $0.60 \mathrm{~g} / \mathrm{cm}^{3}$ [30]. It is also expected that groundnut shell biochar briquette combustion rate maybe longer with the density value obtained compared to raw groundnut shell briquette sample [17].

A compressive value of $0.94 \mathrm{~N} / \mathrm{mm}^{2}$ and $3.66 \mathrm{~N} / \mathrm{mm}^{2}$ were recorded for raw groundnut shell briquette and groundnut shell biochar briquette at $\mathrm{P}>0.05$ as shown in Table 4 . The compressive strength depends on the density, moisture content and lignin content of the biomass materials. The higher the density and decrease in moisture content was found to increase the compressive strength [31].

The results of the ignition propagation are shown in Table 5. The biomass briquettes have short ignition time and will catch fire easily. The ignition propagation was not significant at $(\mathrm{P}>0.05)$ and with the trend of the results obtained for the ignition propagation, it was observed that, the higher density as the ignition propagation is delayed which is in agreement with Davies and Abolude [32]. Similarly, low volatile matter in briquettes is associated with difficult to ignites and burn slowly [33].

The results of the afterglow time are shown in Table 5. The afterglow values for raw groundnut shell briquette and groundnut shell biochar briquette are $44 \mathrm{Sec}$, and $63 \mathrm{Sec}$ respectively. It is noted that, the higher value recorded for groundnut shell biochar briquette could be attributed to the reduction in the porosity exhibited between inter and intra particles which does not enable easy infiltration of oxygen and outflow of combustion briquettes [18]. The longer the afterglow time and slow propagation suggests that such briquettes will burn easier with intensity for a long time than other briquettes and could be attributed to its high porosity and nature of its particle size [34]. The results of the combustibility test are presented in Table 5. This was carried out to compare the cooking efficiency of the briquettes. It measured the time taken for each set of briquettes to boil an equal volume of water under similar condition. From the results obtained, it was observed that, the higher calorific value recorded for groundnut shell biochar briquette actually reduced the time taken to boil the same quantity of water and improving the residence time for the briquettes to undergo complete combustion [35].

The fuel burning rate was defined by the rate of amount of fuel burnt to the time taken to boil $100{ }^{\circ} \mathrm{C}$ as shown in Table 5; the groundnut shell biochar briquette has the higher fuel burning rate of $1.68 \mathrm{Kg} / \mathrm{hr}$ while the raw groundnut shell briquette had the lower fuel burning rate of $0.80 \mathrm{Kg} / \mathrm{hr}$. The briquettes with higher burning rate are economical as smaller amount of it is required to cook a given quantity of food [36].

The SEM micrograph of raw groundnut shell and groundnut shell biochar was shown in Figure 4 and 5. The raw groundnut shell had porous rough surface arranged uniformly as stacked layers. Pyrolysis causes substantial transformation to the surface morphology of the chars, this is probably caused by the increased rupture of the biomass structure due to release of more volatile matter as the heating temperature was increased [37].

Pyrolysis distorted the fine collagen fiber network [38]. The finer the particle size, the easier the compaction processes during densification and the better the quality of the briquette [39]. Fine particles give a larger surface area for bonding.

Figure 2 and 3 show the spectral for raw groundnut shell material and pyrolyzed groundnut shell biochar respectively. It is evident that pyrolysis of groundnut shell aids in the surface chemistry modification and disruption of structural components. The reduction of peaks at the range of $1500 \mathrm{~cm}^{-1}$, which represents aromatic $\mathrm{C}=\mathrm{C}$ and $\mathrm{C}=\mathrm{O}$ stretching, shows that there is lignin decomposition after the pyrolysis. The peak reduction was greatly noticed in biochar sample. The intensity of the hydroxyl peak $(\mathrm{O}-\mathrm{H})$ which decrease for the biochar sample indicates that the loss of hydrogen and oxygen atoms due to the breaking bond from hydroxyl group.

\section{Conclusion}

The study investigated and compared the effects of pyrolysis on the physicochemical and combustion properties of groundnut shell biochar briquette and raw groundnut shell briquette. The finding of the study for all the essential parameters showed that the groundnut shell biochar briquette had a better performance than the raw groundnut shell briquette investigated. Albeit, the calorific value which is the heating property revealed that the briquettes possessed a suitable properties to be used for household cooking as well as an alternative sources of fuel in small scale industries. Conclusively, pyrolyzing a biomass prior briquette production improves its quality as well as its combusting performance.

\section{References}

[1] Mahalingam A., Nagappan B., Jayaram P., Nagalingeswara B. Investigating the Physio-chemical Properties of Densified BiomassPellet Fuels from Fruit and Vegetable Market Waste, Arabian Journal for Science and Engineering (2019), https://doi.org/10.1007/s13369-019-04294-8.

[2] Demirbas, A. Biomass resources for energy and chemical industry. Energy Education, Science and Technology. 5 (2000), 21-45.

[3] Ajimotokan H. A., Sher I. I. Thermodynamic performance simulation and design optimisation of trilateral-cycle engines for waste heat recovery-topower generation, AppliedEnergy (2015). 154: 26-34.https://doi.org/10.1016/j.apenergy.2015.04.095.

[4] Ajimotokan H.A. A Study of Trilateral Flash Cycles for Low-Grade Waste Heat Recovery-to Power Generation Ph.D. Thesis, (2014). Energy and Power Division Cranfield, Cranfield University, UK.

[5] Khennich M., Galanis N. Thermodynamic analysis and optimization of power cycles using a finite low-temperature heat source, International Journal of Energy Resources. (2012). 36: 871-885.https://doi.org/10.1002/er.1839.

[6] Obi O.F., Okongwu K.C. Characterization of fuel briquettes made from a blend of rice husk and palm oil mill sludge, Biomass Conversion and Biorefinery, (2016). 6 (3): 449-456https://doi.org/10.1007/s13399-016-0206-x.

[7] AjimotokanH.A.,Ehindero A.O., Ajao K.S.,Adeleke A.A.,Ikubanni P.P.,Shuaib-BabataY.L.Combustion characteristics of fuel briquettes made from charcoal particles and sawdust agglomerates, Scientific African (2019). 6 e00202, Pp 1-8.https://doi.org/10.1016/j.sciaf.2019.e00202. 
[8] Trubetskaya A., Leahy J. J., Yazhenskikh E., Muller M., Layden P., Johnson R., Stahl K andMonaghan R. F. D. Characterization of woodstove briquettes from torrefied biomass and coal. Energy, (2019). 171:853-865. https://doi.org/10.1016/j.energy.2019.01.064.

[9] Liu D, Guo X, Xiao B. What causes growth of global greenhouse gas emissions? Evidence from 40 countries. Science and Total Environment, (2019). 661:750-766. https://doi.org/10.1016/j.scitotenv.2019.01.197.

[10] Aziz, S.M.A., Rafeah, W., Zainab, N. \&Sinin, H. Bio-oils from microwave pyrolysis of agricultural wastes. Fuel Processing Technology (2013). 106: 744-750.https://doi.org/10.1016/j.fuproc.2012.10.011.

[11] Xiu, S. and Abolghasem S. Bio-oil production and upgrading research: A review. Renewable and Sustainable Energy Reviews (2012). 16(7): 44064414https://doi.org/10.1016/j.rser.2012.04.028.

[12] Adegoke, I. AandFuwape, J. A. combustion properties of briquettes as affected by Production process. Proc. $1^{\text {st }}$ Annual Conf. in Forests and Forest Products, 16th 19th April 2008, FUTA. Nigeria. Pp 193-197.

[13] Nurhayati A, Fauziah S and Aminu A. S. Bio-Oil and Biochar Derived from the Pyrolysis Of Palm Kernel Shell For Briquette. SainsMalaysiana (2017). 46(12): 2441-2445.https://doi.org/10.17576/jsm-2017-4612-20.

[14] Ige A.R, Elinge C.M, Aliyu M, Gwani M and Lawal L.G. Optimization of groundnut shell fast pyrolysis for the production and characterization of bio-oil using fabricated fixed bed reactor. International Journal of Advanced Chemistry, 8(2), (2020) 217-224.

[15] Sallau., A.A, Hassan., U.F, Ekanem., E.O, Jauro A and Kolo A.M (2021). Effect of carbonization temperature on properties of char and from coconut shell. International Journal of Advanced Chemistry, 9(1): 34-39.

[16] Obi O. F., C. O. Akubuo and W. I. Okonkwo (2013). Development of an appropriate briquetting machine for use in rural communities. International Journal of Engineering and Advanced Technology, 2 (4): 578-582.

[17] Olawale, J. O., Abdulkadir, B. H., and Barakat, J. I. (2014). Effect of starch and gum Arabicbinders in the combustion characteristics of Briquettes prepared from sawdust, International Journal of Scientific Engineering Research, 5. (3): 1-10.

[18] LasodeO.A ., Balogun A .O., and McDonald A. G. Torrefaction of some Nigerian lignocellulosic resources and decomposition kinetics, Journal Analytical and Applied Pyrolysis. (2014), 109; 47-55.https://doi.org/10.1016/j.jaap.2014.07.014.

[19] Prims M.J., Ptasinski K. J., and Janssen F. J. Torrefaction of wood: part 1: weight loss kinetics, J. Analy. Appl. Pyroly. 77 (1); (2006) 2834.https://doi.org/10.1016/j.jaap.2006.01.002.

[20] Lua, AC, Lau FY, Guo J. Influence of pyrolysis conditions on pore development of oil-palm-shell activated carbons. Journal of analytical and applied pyrolysis; (2006), 76: 96-102.https://doi.org/10.1016/j.jaap.2005.08.001.

[21] Ige A. R, Elinge C. M, Hassan L. G, Adegoke I. A, and Ogala H. Effect of Binder on Physicochemical Properties of Fuel Briquettes Produced From Watermelon Peels. AASCITJournal of Energy. (2018), Vol. 5, No. 2, pp. 23-27.

[22] Katimbo, A., Nicholas, K., Simon, K., Hussein, B. K., and Peter, T. Potential of densification of mango waste and effect of binders on produced briquettes. Agricultural and Engineering International. CIGR Journal, (2014), 16 (4): 146-155.

[23] Garcia R., Pizarro C., Lavin A. V., and Bueno J. L. Characterization of Spanish biomass wastes for energy use. Bioresource Technology, (2012), 103, 249-258, https://doi.org/10.1016/j.biortech.2011.10.004.

[24] Carnaje N, P, Talagon R. B, Peralta J. P, Shah K, Paz-Ferreiro J. Development and characterisation of charcoal briquettes from water hyacinth (Eichhornia crassipes) molasses blend. (2018), PLoS ONE 13(11): e0207135. https://doi.org/10.1371/journal.pone.0207135.

[25] Maninder, R, Singh, K and Grover, S. Using agricultural residues as a BiomassBriquetting: An Alternativesource of energy. Journal of electrical and electronic Engineering (2012),1 (5): 11-15.https://doi.org/10.9790/1676-0151115.

[26] Olorunnisola A. O. Production of fuel briquettes from waste paper and coconut huskadmixtures. Agricultural Engineering International: the CIGR E-Journal. (2007). Manuscript EE06066: 1: 12-15.

[27] Praveena, U, Satya, N. Ramya, K and Sarveswara, R. S (2014). Studies on development of fuel briquettes using biodegradable waste materials, Journal of Bioprocessing and Chemical Engineering 2 (1): 1-10.

[28] Eddine B.T and Salah M. M. Solid waste as renewable source of energy: current and future possibility in Algeria, International Journal of Energy and Environmental Engineering (2012), 3(17): 1-12.https://doi.org/10.1186/2251-6832-3-17.

[29] Adegoke I. A., Ogunsanwo O. Y. Thermal Energy Estimates of Briquettes Produced from Bio Char Sawdust of Gmelina arborea. AASCIT Journal of Energy, (2017), 4(1), 1-4.

[30] Wilaipon, P. Density Equation of Bio-Coal Briquette and Quantity of Maize cob in Phitsamilok Thailand, American Journal of Applied Science, (2008), 6(1): 167-171

[31] Wachira, G.G., Gitau, A.N., Kumani, M.W., and Njoroge, B.N.K. Mechanical properties of sawdust briquettes of Eucalyptus tree species of different binders and press machines. International Journal of Engineering Technology and Advanced Engineering, (2015), Vol.5, Pp.128-136.

[32] Davies, R.M and Abolade, D. O. Physical and combustion characteristics of briquettes made from water hyacinth and phytoplankton sum as binder. J. Combust.(2013), https://doi.org/10.1155/2013/549894.

[33] Sotannde, O.A., Oluyege, A.O., and Aba, G. B. Physical and combustion of charcoal briquettes from neem wood residues. International Agrophysics, (2010), 24: 189-194.

[34] Onuegbu, T. U., Ekpunobi, U. E., I. M., Ekeoma, M. O. and Obumselu, F. O., Comparative studies of Ignition timeand Water boiling Test of Coal and Biomass Briquettes Blend. International Journal Research Applied Science;(2011), 7 (2): pp. 153-159

[35] Oladeji, J.T. The effects of some Processing Parameters on Physical and Combustion Characteristics of Corncob Briquettes. An unpublished Ph.D Thesis of the Department of Mechanical Engineering (2011), Ladoke Akintola University of Technology, Ogbomoso, Nigeria.

[36] Elinge, C.M. Study on the combustion profiles of briquettes from blends of charcoal and some agricultural wastes. An unpublished Ph.D Thesis submitted to Department of Pure and Applied Chemistry, (2016), UsmanuDanfodiyo University, Sokoto, Nigeria.

[37] Nwabue, F.I., Unah, U., Itumoh, E.J. Production and characterisation of smokeless bio-coal briquettes incorporating plastic waste materials. Environmental Technology \&Innovation, (2017), https://doi.org/10.1016/j.eti.2017.02.008.

[38] Tangsathitkulchai, C, Junpirom, S and Katesa, J. Carbon Dioxide Adsorption in Nanopores of Coconut Shell Chars for Pore Characterization and the Analysis of Adsorption Kinetics. Journal of Nanomaterials, 2016. https://doi.org/10.1155/2016/4292316.

[39] Imeh E. O, Ibrahim A. M, Alewo O. A, Stanley I. R and Opeoluwa O. F. Production and Characterization of Biomass Briquettes from Tannery Solid Waste. Recycling, (2017), 2, 17; https://doi.org/10.3390/recycling2040017. 